\title{
A razor blade in the gastrointestinal system
}

\section{Gastrointestinal sistemde jilet bıçağı}

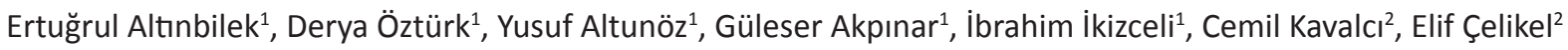

\begin{abstract}
Swallowing of a foreign object is the second most common endoscopic emergency after gastrointestinal bleeding. We aimed to report a case of razor blade swallowing that presented with abdominal pain. A 33-year-old man was brought to the emergency department by his relatives with the complaint of abdominal pain that had started after swallowing a razor blade 1 day earlier. His past history was notable for schizoaffective disorder. A plain abdominal radiogram showed multiple appearances consistent with metallic, shiny foreign objects (razor blade) at multiple levels. J Clin Exp Invest 2015; 6 (3): 309-311
\end{abstract}

Key words: Razor blade, emergency, schizoaffective disorder

\section{INTRODUCTION}

Swallowing of a foreign object is the second most common endoscopic emergency after gastrointestinal bleeding [1]. It occurs more frequently in mentally retarded or psychiatrically ill adults, alcohol intoxication, and with dental prostheses. In the United States nearly 1500 persons die each year due to complications of swallowing foreign bodies [2]. To date, four cases of razor blade swallowing have been reported in the literature. Of these, three occurred in mentally ill subjects [3]. Herein, we aimed to report a case of razor blade swallowing that presented with abdominal pain.

\section{CASE REPORT}

A 33 years old man was brought to the emergency department by his relatives with the complaint of abdominal pain that had started after swallowing a razor blade 1 day earlier. It was learned that the patient had regularly swallowed one or two razor blades a day for one week, but had had no

\section{ÖZET}

Yabancı cisim yutulması Gastrointestinal kanama dan sonra 2. en sık endoskopik acildir. Biz bu vaka sunumunda karın ağrısıyla gelen jilet bıçağı yutulmasını sunmayı amaçladık. 33 yaşında erkek hasta acil servisimize 1 gün önce jilet bıçağı yutulması sonrası başlayan karın ağrısı şikayeti ile geldi. Öz geçmişinde şizoafektif bozukluk vardı. Düz karın grafisinde de çok sayıda metalik, parlak yabancı cisim (jilet bıçağı) görüldü.

Anahtar kelimeler: Jilet bıçağı, acil, şizoafektif bozukluk

abdominal pain, nausea or vomiting and he could pass feces and gas. His past history was notable for schizoaffective disorder for which he had been prescribed some antipsychotic medications that he had not used. Furthermore, it was also learned that he had swallowed many razor blades before, and he had injured his various body parts with sharp penetrating objects.

On admission the patient's overall status was well and he was conscious but he showed aggressive behavior. Having stable vital signs, the patient was found to have many old incision scars in distal parts of both upper extremities. Abdominal examination revealed no tenderness, guarding, or rebound tenderness. Bowel sounds were normoactive, and the other systems were normal. A chest X-Ray did not show any free air beneath diaphragm. An upright plain abdominal radiogram showed multiple appearances consistent with metallic, shiny foreign objects (razor blade) at multiple levels (Figure 1). An abdominal CT showed multiple images of linear intraluminal foreign objects (razor blades) in gastric

${ }^{1}$ Şişli Training and Research Hospital, Emergency Department, istanbul/Turkey

${ }^{2}$ Baskent University Faculty of Medicine, Emergency Department, Ankara/Turkey

Correspondence: Cemil KavalcI,

Başkent University Faculty of Medicine, Emergency Department, Ankara, Turkey Email: cemkavalci@yahoo.com

Received: 04.08.2015, Accepted: 29.09.2015

Copyright @ JCEI / Journal of Clinical and Experimental Investigations 2015, All rights reserved 
antrum, small bowel segments, and cecum (Figure 2). Complete blood count, routine biochemistry, and hemostasis tests were all normal.

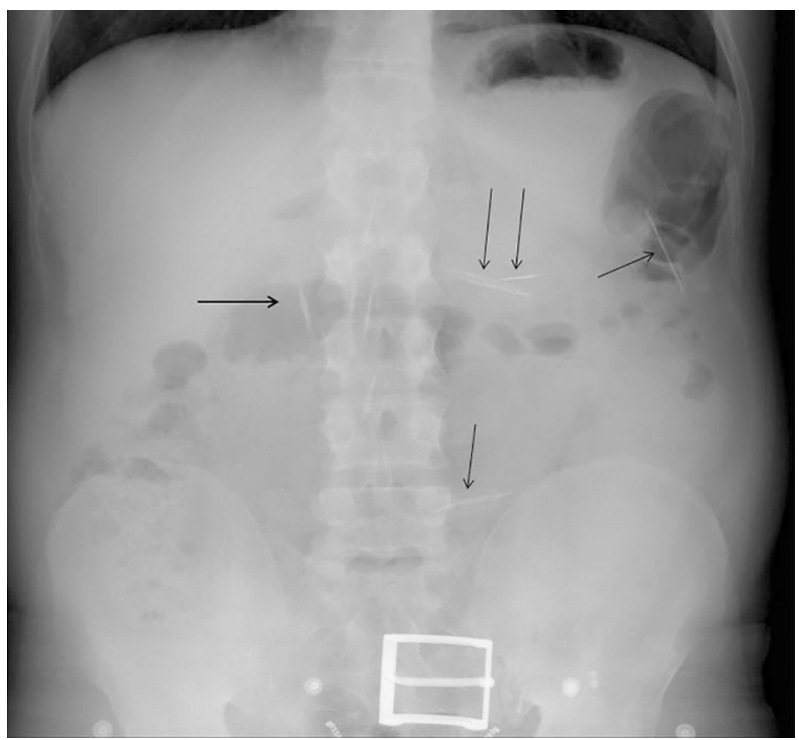

Figure 1. An appearance consistent with a foreign object (razor blade) on upright plain abdominal radiogram

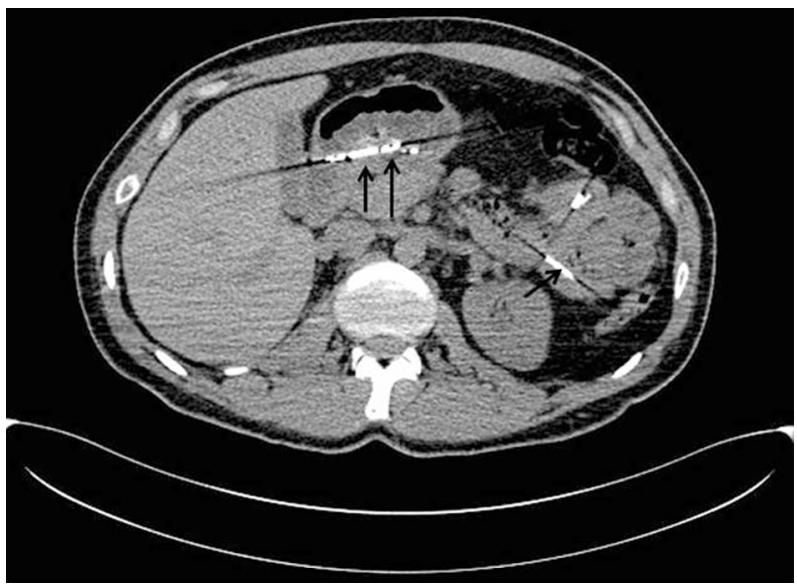

Figure 2. Multiple appearances consistent with foreign objects on abdominal CT

The patient was recommended to undergo an endoscopic study but he refused it. He was admitted to general surgery unit for follow-up. At the $16^{\text {th }}$ hour of admission he left the hospital ward without being permitted by hospital staff after he stated that he defecated all foreign objects. Having been called via telephone at first, third, and seventh days later, he stated that he excreted all foreign objects by defecation, he was fine, and he would not attend any follow-up appointment.

\section{DISCUSSION}

Subjects with psychiatric illness constitute $21 \%$ of the individuals presenting to hospitals after swallowing foreign objects and subjects without psychiatric illnesses make up another 4\% [3-5]. Swallowing foreign objects has been linked with secondary gain in convicts and psychiatric patients [4]. Male gender is an independent factor for this abnormality [6]. Many cases have been reported in patients with schizophrenia [4]. The likelihood of developing complications is particularly higher in psychiatric cases since such cases cannot express themselves and their complaints cannot be fully investigated owing to their psychiatric condition. The diagnosis is mostly made by detailed anamnesis and appropriately selected imaging tests [2]. Physical examination may show signs of obstruction or perforation whereas it may also be completely normal. Radiological modalities can be used for the diagnosis. Plain radiograms can reportedly detect foreign objects at a rate of $87 \%$ [2]. While foreign objects appear mostly radioopaque, fishbone, chicken bone, plastic, or glass objects are harder to spot [2]. Still, however, plain radiograms can give clues about the number, structure, and localization of a foreign object $[2,7]$. When complications such as hemorrhage, perforation, or obstruction are suspected, advanced imaging modalities can be utilized [2]. The foreign objects were also spotted by plain radiogram in our patient, and his physical examination was normal. The razor blades were detected on plain radiogram and they were further characterized by abdominal tomography.

Blaho et al reported that convicts presenting to emergency department after swallowing foreign objects had additional psychiatric disorders. It has been reported that in cases with psychiatric disorders, treatment of the primary disease may fail to prevent swallowing foreign objects [3]. Our patient had schizoaffective disorder.

The preferred management of swallowing sharp objects consists of close monitoring, endoscopy, and surgery [2]. The basic factors determining the treatment approach are the type and gastrointestinal localization of a foreign object. Majority of foreign objects reaching stomach usually leave the gastrointestinal system without difficulty. The largest series in the literature to date is the one published by Velitckov et al, which consisted of 542 cases of swallowing foreign object over a period of 20 years. In this series, foreign objects were spontaneously excreted in $75.6 \%$ of the cases, while endoscopic 
and surgical removal were required in $19.5 \%$ and $4.8 \%$ of the cases, respectively [4].

Slovis et al [5] reported that they followed a patient who swallowed 71 metallic objects (wrench, wire spring, and razor blade) for 8 days, and they removed the objects via gastrostomy on $8^{\text {th }}$ day when objects did not show any sign of passage. They also added that management and follow-up of sharp objects were still controversial, and suggested that the decision between a medical and surgical management approach should be made on the basis of the patient's overall status.

Majority of foreign objects are excreted spontaneously within a week, although swallowing batteries, needles, or sharp objects, or presence of gastric outlet syndrome may necessitate a surgical operation [2]. In our case, all razor blades were past the esophagus, without causing any signs of peritoneal irritation. When a foreign object does not pass to duodenum within 5-6 days, it should be removed endoscopically or with gastrotomy [2]. In line with the literature, we planned close follow-up and an endoscopic procedure in our patient, however he refused the latter. He had no elevation in white blood cell count. It was also learned later that he excreted all foreign objects by defecation. A surgical intervention should be avoided whenever possible in swallowing foreign objects since the harm a surgical intervention can do to a patient may be greater than that of a foreign object. It should be kept in mind, however, that surgical operation may always be needed depending on the type, localization, or duration of stay of a foreign object, or when it cannot be removed by endoscopic approach or symptoms are too severe [2,3].
In conclusion, emergency department physicians should always remember the possibility of swallowing a sharp object when special patient populations present with atypical complaints. These patients are preferably managed by close followup and endoscopic intervention. Since the victims of these incidents are usually mentally ill subjects, an appointment with a psychiatrist for psychiatric evaluation should also be arranged.

\section{REFERENCES}

1.Weiland ST, Schurr MJ. Conservative management of ingested foreign Bodies. J Gastrointest Surg 2002;6:496-500.

2.Eisen GM, Baron TH, Dominitz JA, et al; American Society for Gastrointestinal Endoscopy. Guideline for the management of ingested foreign bodies. Gastrointest Endosc 2002;55:802-806.

3. Blaho KE, Merigian KS, Winbery SL, et al. Foreign body ingestions in the Emergency Department: case reports and review of treatment. J Emerg Med 1998;16:21-26.

4.Velitchkov NG, Grigorov GI, Losanoff JE, Kjossev KT. Ingested foreign bodies of the gastrointestinal tract: retrospective analysis of 542 cases. World J Surg 1996;20:1001-1005.

5.Slovis CM, Tyler-Werman R, Solightly DP. Massive foreign object ingestion. Ann Emerg Med 1982 Aug;11:433-435.

6.Grimes IC, Spier BJ, Swize LR, et al. Predictors of recurrent ingestion of gastrointestinal foreign bodies. Can J Gastroenterol 2013;27: e1-e4

7.Kefeli A, Başyiğit S, Yeniova AÖ, et al. Foreign bodies in gastrointestinal tract. Dicle Med J 2014;41:195-198. 